\title{
Fedezd fel a természetet
}

\author{
Sztudva Mónika \\ Müvész úti Óvoda és Bölcsőde
}

\begin{abstract}
Absztrakt
Jelen írás a fenntarthatóságra nevelés, környezeti nevelés témakörében mutat be néhány jó gyakorlatot, elsősorban 3-4 éves korosztály részére, így az életkori sajátosságoknak megfelelően játékok, játékos tapasztalat szerzések teszik ki a gyakorlatok zömét, megteremtve a lehetőséget ezek későbbi fejlesztésére, újra gondolására, kreatív alkalmazására. Mindezt pedig történeti, nevelés történeti alapokra, a magyar óvodapedagógiai hagyományokat figyelembe véve teszi.
\end{abstract}

Kulcsszavak: fenntarthatóságra nevelés, környezeti nevelés, jó gyakorlat, játék, neveléstörténeti háttér

\section{Játékok környezetünk kincseivel a 3-4 éves korosztály számára}

Az óvodai nevelés régebbi és jelenleg hatályos alapprogramjainak összehasonlításából kiderül, hogy a környezeti neveléssel foglalkozó részek fokozatosan szélesedő területet ölelnek fel. Az 1971-es programban a környezeti nevelés, mint a külső világ tevékeny megismerése még nem jelenik meg különálló területként. A központosított elvárások nem a gyermeket helyezték előtérbe, ugyanis a „Mindenkinek ugyanannyit, ugyanúgy, ugyanazt” elv merev ideológiai szemlélet sajátos meghatározott keretek közé szorította az óvodapedagógusok munkáját, nem adva teret a pedagógusok módszertani szabadságának. Az 1989-es óvodai nevelési program már enyhíti a korlátokat, mindamellett módszertani, nevelési alapelveket határoz meg a környezeti neveléssel kapcsolatban. A változások ellenére azonban még mindig a konzervatív nevelési szemléletet visz tovább, ugyanakkor az is igaz, hogy az intézményeknek lehetőséget ad a sajátos óvodakép kialakítására.

A 1990-es években az óvodák saját maguk által kidolgozott helyi nevelési programjában a nevelési területek bővebb kifejtési lehetőséget kaptak. A helyi sajátosságok megjelenítésével - belvárosi, külvárosi, budai hegyvidéki, vidéki - az óvodák a környezeti nevelést különbözőképpen tudták megvalósítani. A nevelési irányzatok között megjelentek az alternatív pedagógiák, a reformpedagógiák, mint a Freinet- vagy,- a Waldorf-nevelés elvei, a néphagyományőrzés, illetve a nemzetiségi sajátosságokat magán viselő helyi programok. 


\section{Néhány jellemzö az akkor megjelent óvodai programokból:}

Lépésröl lépésre program: „A Lépésről lépésre (eredeti nevén: Step by Step) gyermekközpontú pedagógiai programot az 1990-es években az Open Society Institute irányításával amerikai szakemberek dolgozták ki. Magyarországon a Soros Alapítvány támogatásával - 1994-ben az óvodai, majd az 1996-/1997-es tanévben az iskolai program került bevezetésre. Ma Középés Kelet-Európa, valamint Ázsia 29 országában működnek Lépésről lépésre programmal gyerekeket oktató, nevelő intézmények, melyek a hatékony és aktív tanulás segítségével teszik alkalmassá a felnövekvő gyerekeket arra, hogy egy demokratikus társadalom hasznos és alkotó tagjaivá váljanak. Magyarországon növekszik azon intézmények száma, amelyek Lépésről lépésre programmal müködnek. A program hazai terjesztője és fejlesztője az Ec-Pec Alapítvány (https://www.ecpec.hu) (https://lepesrollepesre.eoldal.hu/)

Mályva program: „Mályva Integráló-Differenciáló (továbbiakban MINDI) Óvodai Program. Elfogadják a humánus pedagógia két alapvető, mindkét félre egyformán vonatkozó feltételét: az egyén meglévő összes belső értékének kibontakoztatására törekszenek; a kibontakoztatott egyéni emberi értékek hatásait a szűkebb és a tágabb emberi közösség tagjaira is kiterjesztik. Ez a humánus pedagógia az emberből indul ki és ezért emberérdekü." (https:// docplayer.hu/165475306-Malyva-integralo-differencialo-ovodai-program. html)

Epochális rendszerü óvodai nevelés: „Az epochális tanulás olyan rendszer, amelyben: a testnevelés kivételével minden tervezett tanulás kötetlen, mert ez az a szervezeti forma,amelyben a 3-7 éves korú gyermekek képességei jobban aktivizálhatók,amelyben megörizhetik autonómiájukat,önként, de egyszerre maximum nyolc gyerek vehet részt, elkerülhető, hogy legyenek olyan gyerekek (tankötelesek), akik az önkéntesség miatt esetleg rendszeresen nem vesznek részt a szervezett tanulási folyamatban. A tanulási tevékenység epochákban történik, környezetismeret, környezetvédelem, munka, illem és matematikatanulás epochák vannak, melyek helyét és idejét a tanévben az aktualitás (pl. évszak) határozza meg. Ez azt jelenti, hogy a környezeti és matematikai tanulás ciklusokba rendeződve követi egymást. Egy epochába sorolt témakör ( $\mathrm{pl}$. ősz) anyagával több hétig (2-3 hét) lehet foglalkozni. folyamatosan. A naponta ismétlődő feldolgozása mindig az egészből indul, majd a részek egymásra építésével az egészhez tér vissza. Epochális feldolgozás eredményeként megszűnt az ismeret- és tapasztalatszerzés mozaikolása, foglalkozásokra szétesése. A témakör feldolgozásának mélységét mindig az epochális tanulásban résztvevő gyerekek egyénenkénti fejlettsége határozza meg." (https://www.kir.hu/KIR2_INFO/Pub/DokLetolt/PEDPROG-028774-0) 
Tevékenységközpontú program: „A tevékenységközpontú óvodai nevelés a gyermek középpontba helyezését és az óvoda nevelési funkciójának kiteljesítését tekinti alapvető feladatának. A gyermek, fejlődő személyiség, fejlődését genetikai adottságok, a belső fejlődés - az érés - sajátos törvényszerűségei, a spontán és tervszerűen alkalmazott környezeti hatások együttesen határozzák meg." (https://www.kir.hu/KIR2_INFO/Pub/DokLetolt/PEDPROG-202632-0)

A 137/1996. (VIII. 28.) Korm. rendelet Óvodai nevelés országos alapprogramjában A külső világ tevékeny megismerése néven találjuk meg az környezettel és matematikával foglalkozó óvodai nevelési területet, amely négy pontban foglalja össze azokat a törvény adta kereteket, melyek lehetőséget biztosítanak az óvodapedagógusnak egy-egy téma többoldalú feldolgozására „1. A gyermek aktivitása és érdeklődése során tapasztalatokat szerez a közvetlen és tágabb természeti-emberi-tárgyi környezet formai, mennyiségi, téri viszonyairól. A valóság felfedezése során pozitív érzelmi viszonya alakul a természethez, az emberi alkotásokhoz, tanulja azok védelmét, az értékek megörzését. 2. A gyermek miközben felfedezi környezetét, olyan tapasztalatok birtokába jut, melyek a környezetben való, életkorának megfelelő biztos eligazodáshoz, tájékozódáshoz szükségesek. Megismeri a szülőföld, az ott élő emberek, a hazai táj, a helyi néphagyományok, szokások és a tárgyi kultúra értékeit, megtanulja ezek szeretetét, védelmét is. 3. A környezet megismerése során matematikai tartalmú tapasztalatoknak, ismereteknek is birtokába jut a gyermek. Felismeri a mennyiségi, alaki, nagyságbeli és téri viszonyokat: alakul ítélőképessége, fejlődik tér-, sík- és menynyiségszemlélete. 4. Az óvodapedagógus feladata, hogy tegye lehetővé a gyermek számára a környezet tevékeny megismerését, biztosítson alkalmat, időt, helyet, eszközöket a spontán és szervezett tapasztalat- és ismeretszerzésre, a környezetkultúra és a biztonságos életvitel szokásainak alakítására."

2004-2013 között a új óvodai nevelési koncepció került az óvodai nevelés látókörébe a kompetencia alapú programcsomag. „A kompetencia ebben a felfogásban az ismeretek, azok alkalmazási képessége és az alkalmazáshoz szükséges megfelelő motivációt biztosító attitüdök összessége. Kompetencia alapú oktatáson a képességek, készségek fejlesztését, az alkalmazásképes tudást középpontba helyező oktatást értjük, amely lehetővé teszi, hogy a különkülön fejlesztett kompetenciák szervesüljenek, és alkalmazásuk életszerű keretet, értelmet nyerjen a gyerekek számára." írja Pála Károlya: Kompetencia alapú oktatási programcsomagok fejlesztése Magyarországon címü írásában (Pála, 2009). Értelmezése szerint a fejlesztés területeit és a kulcskompetenciákat az alábbi területek alkotják: óvodai nevelés, szövegértés-szövegalkotás, matematikai-logikai kompetencia, idegen nyelvi kompetenciák, szociális, életviteli és környezeti kompetenciák, életpálya-építési kompetencia és, infokommunikációs technológiák. 
A programcsomag kiemelten fontosnak tartja az integrációt. „Az integráció fogalma a Magyar értelmező kéziszótár definíciója szerint a különálló részeknek valamely nagyobb egészbe, egységbe való beilleszkedését, beolvadását jelenti. Az integráció a nevelésben és a pedagógiában a fogyatékkal élő, akadályozott és az ép egyének közös élet- és tanulási térben végbemenő együttnevelését, oktatását és képzését jelenti, ezáltal minden résztvevőnek optimális fejlődési lehetőséget biztosít. Az integrált nevelés a köznevelésben az esélyteremtés, az esélyegyenlőtlenségek csökkentésének eszközeként értelmezhető. Az integráció a szakértői vélemény figyelembevételével mindenki számára nyitottá teszi a nevelési-oktatási intézményeket a tapasztalható eltérő képességektől függetlenül." (http://www.jgypk.hu/mentorhalo/tananyag/Az_vodapedaggus_feladata_a_sajtos_nevelsi_igny_gyermekek_nevelsben/szegregci_s_integrci_fogalmnak_rtelmezse.html)

A 363/2012. (XII. 17.) Korm. rendelet, az óvodai nevelés alapprogramja így fogalmaz: „A külső világ tevékeny megismerése kapcsán négy pontban: 1. A gyermek aktivitása és érdeklődése során tapasztalatokat szerez a szűkebb és tágabb természeti-emberi-tárgyi környezet formai, mennyiségi, téri viszonyairól. A valóság felfedezése során pozitív érzelmi viszonya alakul a természethez, az emberi alkotásokhoz, tanulja azok védelmét, az értékek megőrzését. 2. A gyermek, miközben felfedezi környezetét, olyan tapasztalatok birtokába jut, amelyek a környezetben való, életkorának megfelelő biztos eligazodáshoz, tájékozódáshoz szükségesek. Megismeri a szülőföld, az ott élő emberek, a hazai táj, a helyi hagyományok és néphagyományok, szokások, a közösséghez való tartozás élményét, a nemzeti, családi és a tárgyi kultúra értékeit, megtanulja ezek szeretetét, védelmét. 3. A gyermek a környezet megismerése során matematikai tartalmú tapasztalatoknak, ismereteknek is birtokába jut és azokat a tevékenységeiben alkalmazza. Felismeri a mennyiségi, alaki, nagyságbeli és téri viszonyokat: alakul ítélőképessége, fejlődik tér-, sík- és mennyiségszemlélete. 4. Az óvodapedagógus feladata, hogy tegye lehetővé a gyermek számára a környezet tevékeny megismerését. Biztosítson elegendő alkalmat, időt, helyet, eszközöket a spontán és szervezett tapasztalat- és ismeretszerzésre, a környezetkultúra és a biztonságos életvitel szokásainak alakítására. Segítse elő a gyermek önálló véleményalkotását, döntési képességeinek fejlődését, a kortárs kapcsolatokban és a környezet alakításában, továbbá a fenntartható fejlődés érdekében helyezzen hangsúlyt a környezettudatos magatartásformálás alapozására, alakítására." (https:// net.jogtar.hu/getpdf?docid=\&printTitle=363/2012.+\%28XII.+17.\%29+Kor m.+rendelet)

Az évek folyamán az óvodai nevelés alapprogramja sokat változott. A jelenleg érvényben lévő Óvodai nevelés országos alapprogramja változatlanul viszi tovább a környezetünkkel kapcsolatos feladatokat érintő alapelveket. Az óvodapedagógusok figyelmét a gyermeki érdeklődés építésére, az élmény és tapasztalatszerzésre, a felfedező tudásra, a matematikai jelenségek megtapasztaltatására irányítja. Az óvodapedagógus feladata, hogy ezen ismeretek 
megszerzésére, rendszerezésének elősegítésére, helyet, időt, alkalmat biztosítson, illetve, hogy a gyermeki tudás elmélyítése céljából használja ki a spontán adódó nevelési helyzeteket. Támogassa, segítse a gyermeket a döntési, véleményalkotási folyamatában, kortárs kapcsolatai alakulásában, továbbá a fenntartható fejlődés, a helyes, kulturált környezeti magatartás kialakításában. Jelen történeti áttekintés azért is fontos, mivel általa kimutatható, hogy miként formálódott a mai szemlélet és gondolkodás az óvodai környezeti neveléssel kapcsolatban.

A következőkben nézzük meg, hogy az általam ajánlott játékok, játékos feladatok hogyan illeszthetők be a mindennapi nevelési folyamatba. Óvodába lépéskor a gyermekek már rendelkeznek a saját környezetükre vonatkozó ismeretekkel. A már ismert és magukkal hozott ismeretek egyre szélesebb spektrumot fednek le. Feladatunk, hogy az élmény-, és tapasztalatszerzés módszerein keresztül olyan ismereteket adjunk számukra, melyek előkészítik a későbbi ismeretek rendszerezését és alkalmazását.

A külső világ tevékeny megismerése matematikai tartalommal az egész nevelési évben komplexen illene, hogy megjelenjen. Hiszem, hogy a környezeti jelenségek mindig új és újabb lehetőséget kínálnak számunkra. Az évszakok, váltakozása, a növények valamint az időjárás megfigyelése mindig jelen vannak a foglalkozások és így a tervezés folyamán. Igyekszünk felhasználni ezeket a jelenségeket a játékainkban. A nevelés folyamatát érintő őszi tervezéshez kapcsolódó leginkább a kiscsoportos korosztály számára ajánlottak, azonban ezeket tovább lehet fejleszteni a nagyobbak számára is. A matematikatartalmak egyszerü alapjait adják a gyermekek matematikai képességének fejlesztéséhez. Az óvodai programok jellemzője a projektekben való anyagfeldolgozás, mely időt és lehetőséget ad a témák sokoldalú feldolgozására. Projektmódszer: „A projekt egy olyan sajátos tanulási egység, tanulási technika, amely a megismerés fő forrásává az önálló és csoportos tapasztalást teszi. Más szóval a projekt egy ismeretszerzési folyamat, amely az elsajátítást egy alkotó folyamat részeként és eredményeként valósítja meg. A módszer lényege nem kizárólag az, hogy a tanulók egy-egy problémára megoldást találjanak, hanem az, hogy a lehető legtöbb összefüggést és kapcsolódási pontját is felfedjék. A passzív befogadó és feldolgozó magatartás helyett a diáknak lehetősége van saját meglévő képességeinek, viselkedési formáinak kipróbálására, és újak kialakítására. A projektmódszer fó értéke, és egyben leginkább hasznosuló eleme, maga a munkafolyamat, a munka konkrét eredményei és végtermékei mellett. Vagyis a projektmunka során megvalósuló ismeretelsajátítás mellé fontosságban felzárkózik maga a gondolkodási folyamat, valamint az egyéb gyakorlati tevékenységek megvalósítása során szerzett tapasztalatok, élmények szellemi és érzelmi hatása". (http://www.okm.gov.hu/ amieuropank/roviden.html) 


\section{A játékok}

Falevél-válogatás (1. ábra), a faágakról leszedett levelek összegyűjtése és szétválogatása (2. ábra), a halmazalkotás alapjait próbálja játékos formában átadni a gyermeknek. Több lehetőséget ad a külső óvodai vagy akár az otthoni környezet

Rajzold körbe az ujjaddal! Lépd le! Vizuális szempontból a falevél ujjal való körberajzolása belső kép leképezését eredményezi. A gyermek megtapasztalja a falevél anyagát, megvizsgálhatja a szerkezetét, nagyítóval megnézheti az erezetét. Megszámlálhatja a falevél csúcsait, öszszehasonlíthatja a falevelek formáját. (3, 4. ábra). A nagyban kirajzolt falevelek lelépése egyenként vagy csoportosan szintén a belső képkialakítást segíti. A játék az egymáshoz való alkalmazkodást, a kivárást, a térben való tájékozódást, a térből síkba való leképezést készíti elő. Ha a tér lehetővé teszi, egyszerű versenyjátékot is szervezhetünk a gyermekeknek. Kincskeresés játék a gyerekek bátorságát is próbára teszi, hiszen egy számukra „idegen anyagba szükséges belenyúlni és megkeresni a kincseket (8. ábra). Kis csoportos gyerekek is képesek tíz percig is játszani, mivel a figyelmüket leköti a kincsek keresgélése, az új közegben kézzel való - vakon tájékozódás. Tőlünk függ, mennyi kincset rejtünk el (7. ábra). A kincsek szétválogatása, sorba rendezése szintén a matematikai tapasztalatok alakítását segíti elő (10. kép). A kincsek megnevezése, származási helyük (Honnan való a makk?) a környezetről való tudásukat bővíti (9. ábra).

A mi fánk játék egy közös alkotás a gyerekek által már kiválogatott, rendszerezett, megvizsgált falevelekből. A közös munka mindig is összehozza a gyerekeket. A saját falevél (ő hozta) felragasztása, (11, 12. kép) a későbbiekben a gyűjtő munka fontosságát fejezi ki. A falevelek különbözősége érdekes lehetőséget ad számunkra, hogy rávilágítsunk, mi sem vagyunk egyformák, ahogy a falevelek sem, mégis jól megértjük egymást. Egyszerűbben fogalmazva, indirekt a másság elfogadására nevelhetünk. Az, hogy rajzzal kiegészítjük a fát, egy újabb komplex feladat a gyermeknek, hiszen a faleveleket ki kell kerülni, arra nem, rajzolunk, mert összetörhet (13. kép). A kész fával tovább játszhatunk, megfigyelhetjük, melyik fajta falevélből van több, kevesebb ugyanannyi, milyen színük, melyiket ki hozta, ezekhez a falevelekhez a jelüket is odarajzoljuk. Tehát a két egymástól elválaszthatatlan nevelési terület a külső világ tevékeny megismerése és a matematikatartalom együttesen jelenik meg.

A szem-kéz koordináció fogalma: „A szem-kéz koordináció azt a képességet jelenti, hogy a látást és a kéz mozgását célzottan összekapcsoljuk. Ezek az alapvető képességek előfeltételei mindenféle tevékenységnek, így az írás és olvasás elsajátításának is. A gyermek akkor tud a vonalközben írni, ha a szemével úgy tudja követni a keze mozgását, hogy közben nem a kezére, hanem a leírt szövegre néz. A perifériás látását használja a keze irányításához. A 3-4 éves gyermekeknél a vizuális észlelés elsősorban a mozgáson és a testséma gyakorlatain keresztül fejlődik. Az 5-6 éves gyerekeknél azonban célzott, direkt vizuális (látás-)fejlesztés is szükséges. A szem kéz koordináció egy bonyolult 
folyamat, reflexek leépülése, tudatos cselekvések begyakorlásának sorozatából áll." https://mozgasfejlesztes.blog.hu/2011/11/20/a_szem_kez_koordinacio

\section{Játékleírások}

\section{Falevélválogatás}

Az összegyüjtött faleveleket a gyermekek több szempont alapján is kiválogathatják. Természetesen nevezzük meg az adott fát, melyen a levél növekedett. Válogatási szempontok lehetnek szín, méret, forma.

Fejlesztési területek:

Szem-kéz koordináció

Szándékos figyelem

Kivárás

Feladattudat

Megfigyelőképesség
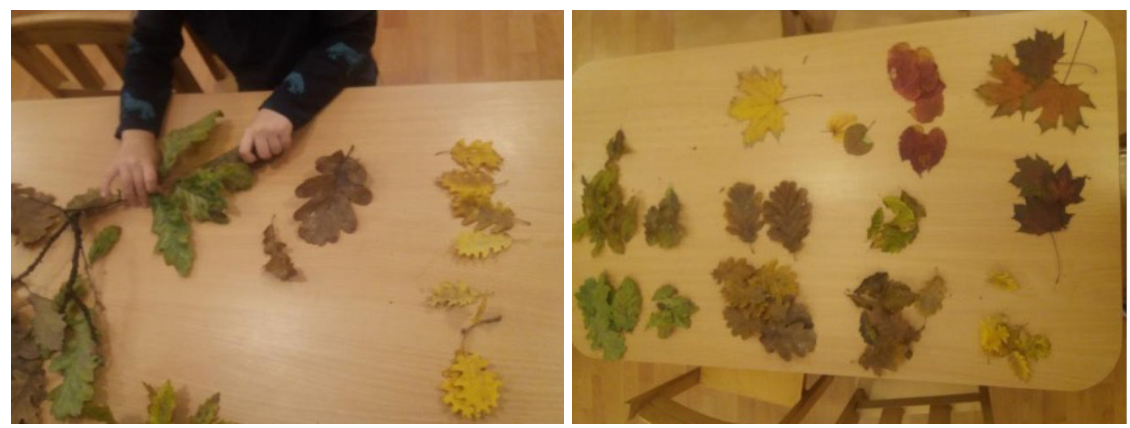

1. ábra

Falevélválogatás

\section{Rajzold körbe az ujjaddal! Lépd le!}

A gyerekek választanak egy számukra tetsző falevelet. Ezt az ujjukkal a levegőben vagy az asztalon körberajzolják. Következő lépésként a falevél mintáját lerajzoljuk egy csomagolópapírra és azt a gyerekek lelépik.

Fejlesztési területek:

Szem-kéz koordináció

Szem-kéz-láb koordináció

Szándékos figyelem

KivárásEgyensúlyérzék

Tájékozódás térben

Feladattudat

Megfigyelőképesség 

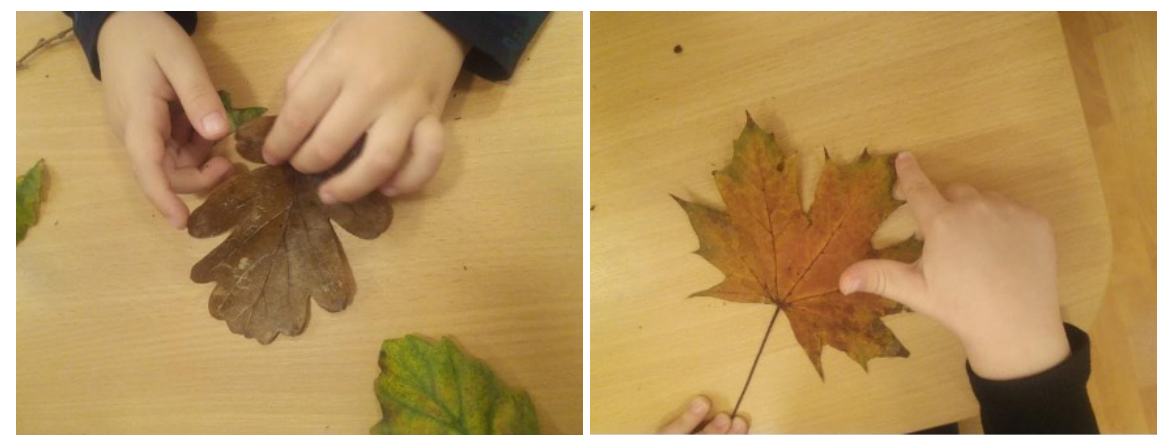

3-4. ábra

Kézügyesség
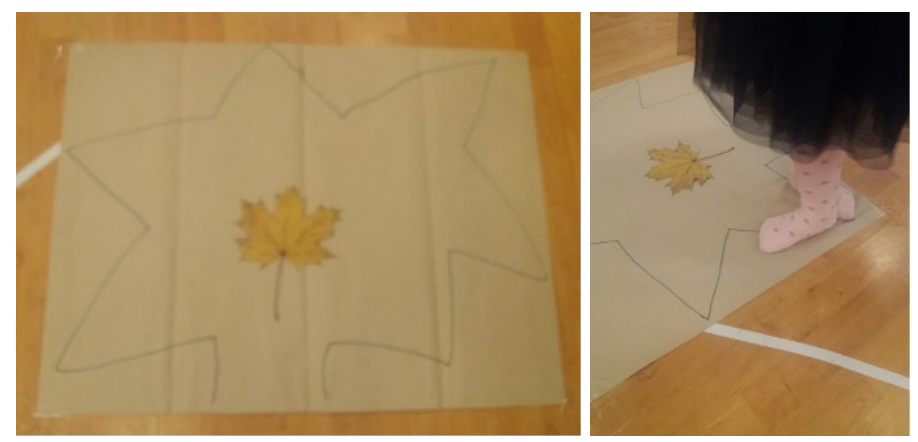

5. ábra

Lábbal

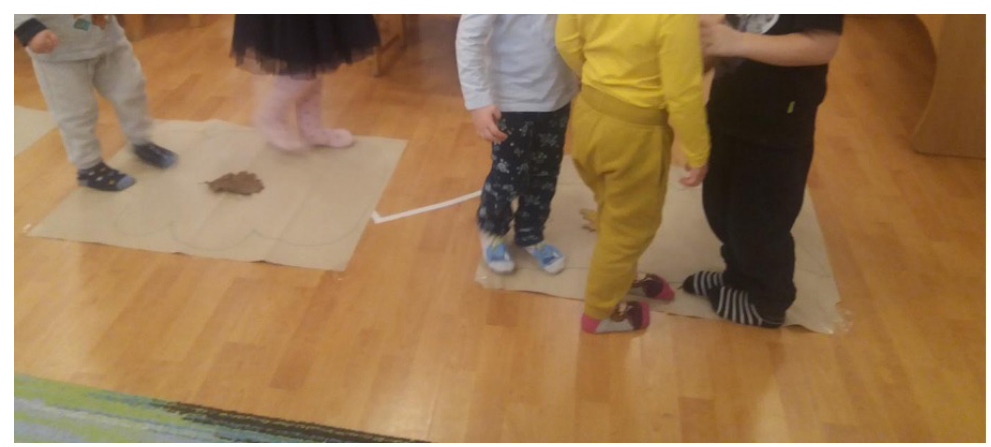

6. ábra

Csoportban 


\section{Kincskeresés}

Vegyünk egy mély tálat vagy edényt. Töltsük meg rizzsel, kukoricával, vagy tritikáléval (a tritikálé a búza és a rozs keresztezésével létrehozott szemes búzához hasonló takarmánynövény). Rejtsünk el benne gesztenyét, makkot, követ, tobozt, diót. Az elrejtett termések számosságánál vegyük figyelembe a korosztályt jellemző sajátosságokat. Ezeket kerestessük meg a gyerekekkel. Lehet két kézzel keresgélni, az ügyesebbek akár egy kézzel is keresgélhetnek. Ezek után ismét lehet méret, termésfajta szerinti válogatást, csoportosítást játszani.

Fejlesztési területek:

Szem-kéz-koordináció

Tapintás, érzékelés

Feladattudat

Közösségi nevelés

Megfigyelöképesség

Számolás
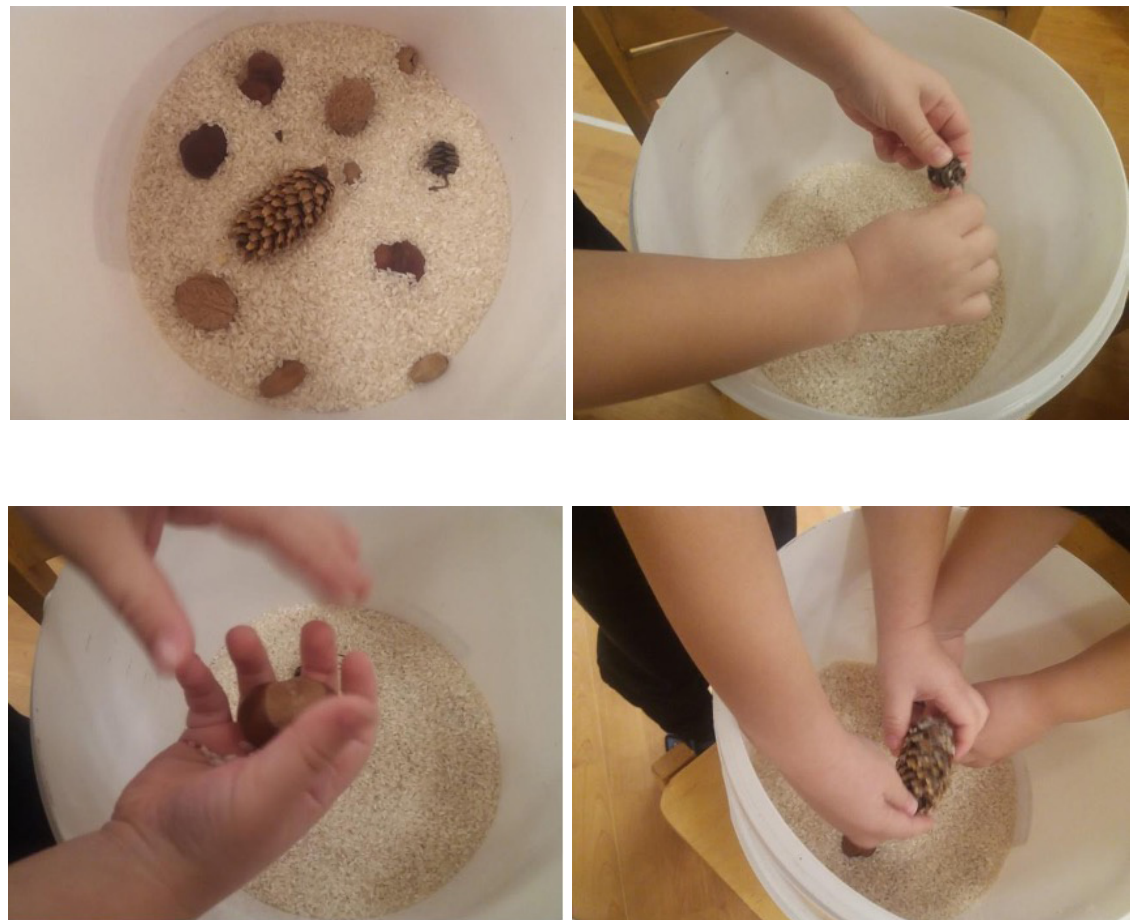


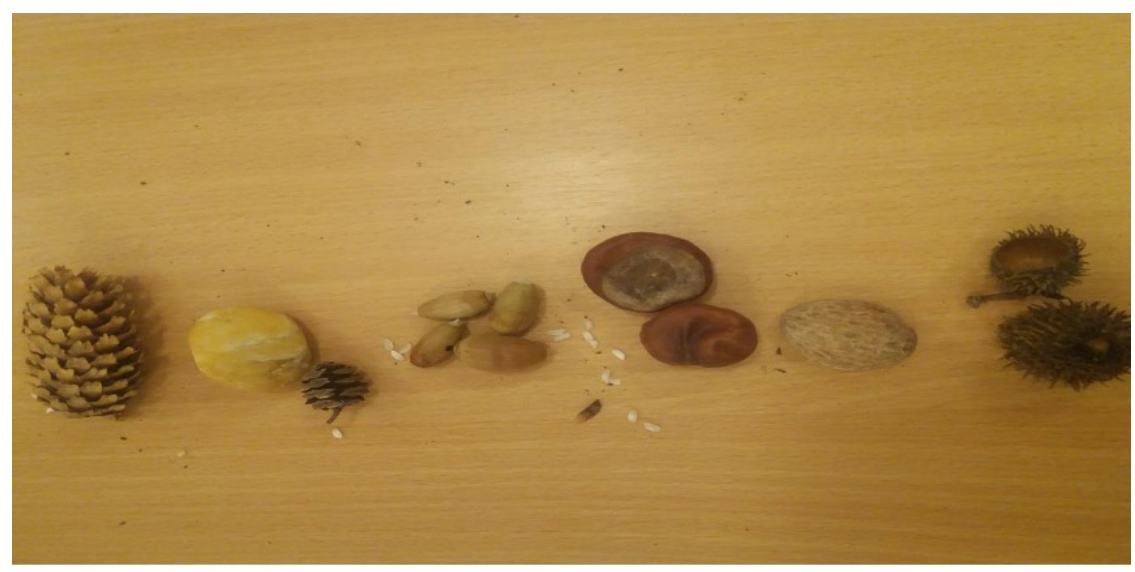

7-11. ábra

Kincskeresés

4. A mi fánk

Az összegyüjtött falevekből egy őszi varázsfát is készíthetünk, a kicsik nagyon szeretik a közös munkát. Szükségünk lesz csomagolópapírra, melyre a fa ágait és törzsét is megrajzoljuk. A többit a gyerekekre bízzuk, mindenki felragaszthatja a számára tetsző levelet, vagy azt, amelyet ő hozott.

Fejlesztési területek:

Közösségi nevelés - együttműködési készség

Szem-kéz koordináció

Tapintás, érzékelés

Tájékozódás térben és síkban
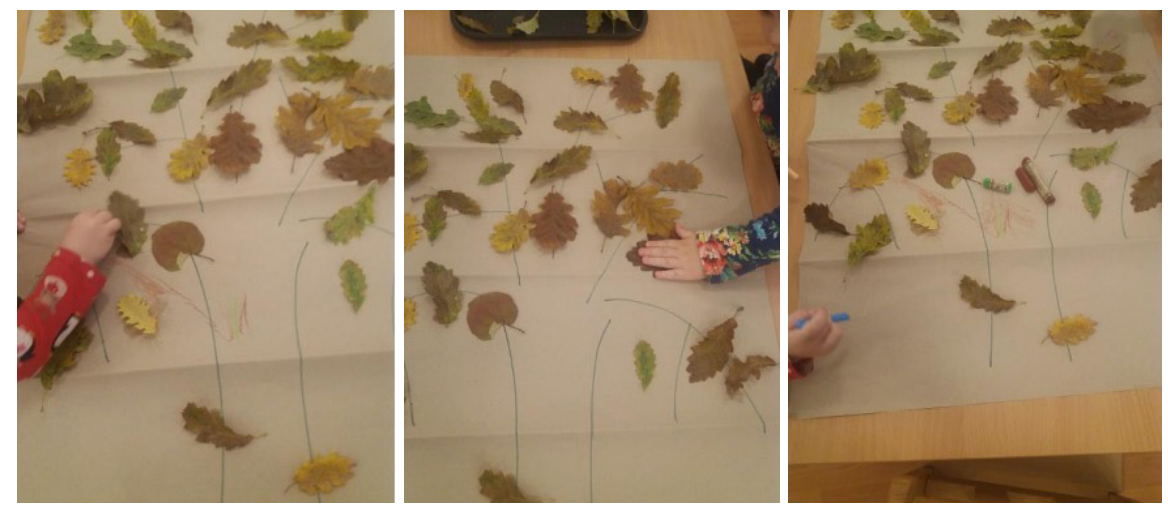

\section{2-14. ábra \\ A mi fánk}


Az előzőekben rövid áttekintést kívántam nyújtani az óvodai programok említése által arról, hogyan jelent, jelenik meg, alakult át a ma ismert foglalom: a külső világ tevékeny megismerése matematikai tartalommal. Ez azért fontos, mert a társadalmi változások során finom átalakuláson keresztül ment megfogalmazások ma már talán lefedik a teljes tartalmat, melyet nekünk, pedagógusoknak érdemes gazdagítani. A folyamatos megújulás a nevelési folyamatok szükségszerüsége. Környezetünk tapintható, látható érzékelhető valóságát, fontos megőriznünk a gyermekek számára. Nem elég megnézni a képernyőn, látni, érezni szükséges, hogy megőrződjön, átadódjon.

A mi óvodánk külső világ tevékeny megismerését segítő környezeti nevelés számára kiváló színtér. A kertben lévő ős tölgyfák, tuják, fenyők, mind kincseket adnak a kezünkbe. Vétek lenne ezt nem felhasználni a gyermekek ismereteinek bővítésére, élmények nyújtására, a közvetlen tapasztalatszerzésre. Járjunk nyitott szemmel és szívvel.

\section{Internetes források}

Illés, V. (é. n.). Projektmódszer az oktatásban. http://www.okm.gov.hu/amieuropank/ roviden.html (2021.04.09.)

Fehér, A. (2006). Játszunk? Természetesen! A világ befogadásának elérhetösége. suliNova Közoktatás-fejlesztési és Pedagógus-továbbképzési Kht. https://www. gyeregyalog.hu/dox/jatszunk_javitva.pdf (2021.04.09.)

F. Nagy Zs. (é. n.). Természetismereti játékok. http://www.nimfea.hu/programjaink/ zoldszem/termismmain.htm

Kiss, F. \& Zsiros, A. (2006). A környezeti neveléstől a globális nevelésig. Oktatási segédanyag. https://www.nyf.hu/ttik/sites/www.nyf.hu.ttik/files/doc/kornyezeti_ neveles.pdf (2021.04.09.)

Pála, K. (2009). Kompetencia alapú oktatási programcsomagok fejlesztése Magyarországon. https://ofi.oh.gov.hu/tudastar/hazai-fejlesztesi/pala-karoly-kompetencia (2021.04.09.)

Óvodai nevelés országos alapprogram 137/1996. (VIII. 28.) Korm. rendelet. http:// www.knok.adatpark.hu/letoltesek/dokumentumok/OAP-1996.pdf (2021.04.09.)

Óvodai nevelés alapprogram 363/2012. (XII. 17.) Korm. rendelet. https://net.jogtar. hu/getpdf?docid $=$ a1200363. kor \&targetdate $=\&$ printTitle $=363 / 2012 .+\% 28 X I I .+1$ 7.\%29+Korm.+rendelet (2021.04.09.)

Óvodai nevelés országos alapprogram. https://net.jogtar.hu/getpdf?docid=a1200363. kor \&targetdate $=\&$ printTitle $=363 / 2012 .+\% 28$ XII $.+17 . \% 29+$ Korm.+ rendelet (2021.04.09.)

Villányi, Gy. (2009). A környezeti nevelés alakulása az óvodai nevelésben - úton a zöld óvoda felé. https://ofi.oh.gov.hu/tudastar/gyakorlatkozelben/kornyezeti-neveles. (2021.04.09.) 


\section{Óvodai programok}

Epochális rendszerủ óvodai nevelés: https://www.kir.hu/KIR2_INFO/Pub/ DokLetolt/PEDPROG-028774-0 (2021.04.09.)

Környezeti Nevelési Program tervezete: http://mkne.hu/konkomp/S1_KNP_ tervezet_2004.pdf (2021.04.09.)

Lépésről lépésre program: https://lepesrollepesre.eoldal.hu/ (2021.04.09.)

Mályva program: https://docplayer.hu/165475306-Malyva-integralo-differencialoovodai-program.html (2021.04.09.)

Mesélő természet - Beszélol környezet óvodai program: http://www.tiszalokiovoda.tonline.hu/dokumentumok/nevprg.pdf (2021.04.09.)

Tevékenység központú program: https://www.kir.hu/KIR2_INFO/Pub/DokLetolt/ PEDPROG-202632-0 


\section{Sztudva, M.}

\section{Let's discover our nature}

In the topic of education for sustainability and environmental education, this article tries to present some good practices, especially for 3-4-year-olds. Thus, according to age-specific characteristics, acquisitions of games and playing experience make up the majority of the exercises creating the opportunity for their later development, rethinking and creative application. It does all this on a historical and educational basis, considering to the Hungarian kindergarten pedagogical traditions.

Keywords: education for sustainability, environmental education, good practice, game, educational history background

Sztudva Mónika: https://orcid.org/0000-0002-5709-9393 